\title{
INHIBITION OF PREGNANCY-BLOCK IN MICE BY HANDLING
}

\author{
H. M. BRUCE, R. B. LAND* AND D. S. FALCONER $\dagger$ \\ Department of Investigative Medicine, Tennis Court Road, Cambridge, and \\ Institute of Animal Genetics, University of Edinburgh
}

(Received 19th Fune 1967)

\begin{abstract}
Summary. Pregnancy-block after exposure of recently inseminated females to strange males was studied in mice of the $Q$ strain. In one series of experiments the incidence of blocked pregnancy was very low. This strain displayed a normal increase in the frequency of oestrus when the females were exposed to males, hence the low pregnancy-block rate could not be attributed to anosmia. In other experiments, $Q$ females displayed a high incidence of pregnancy-block after a period of adaptation. The initial low rate of pregnancy-block was evidently due to disturbance resulting from unaccustomed daily handling during the test.
\end{abstract}

\section{INTRODUCTION}

The occurrence and incidence of oestrus in laboratory mice, Mus musculus, is influenced by social signals (Whitten, 1956, 1958), and implantation in recently inseminated females may be prevented by exposure of the fermale to the odour of strange males (Bruce, 1959; Bruce \& Parrott, 1960). This is also true for wild Mus musculus (Chipman \& Fox, 1966) and for Peromyscus (Eleftheriou, Bronson \& Zarrow, 1962). Certain inbred strains of mice do not display pregnancy-block (Marsden \& Bronson, 1965), although others manifest it to a high degree (Bruce, 1966). The possibility that failure of pregnancy-block is due to olfactory impairment has been examined in a vigorous, outbred strain, the $\mathbf{Q}$ strain. The experiments have shown that the abnormally low rates of pregnancyblock sometimes manifest by this strain result, not from a sensory defect, but from disturbance due to handling.

\section{MATERIALS AND METHODS}

Two strains of mice were studied. The Q strain was developed in Edinburgh by Falconer. Half of the ancestry came from crosses between two strains which had been selected for large body size, one which had been selected for small body size, and a fourth which had been selected for high litter size; the remaining half of the ancestry came equally from an unselected non-inbred strain and

* Present address: Animal Breeding Research Organization, King's Buildings, Edinburgh 9.

$\dagger$ Agricultural Research Council, Unit of Animal Genetics. 
an inbred strain (JU) derived from it. The $P$ strain mice used for comparison were out-bred albino, maintained as a closed colony for many years and derived from a few pairs purchased from a dealer.

In Edinburgh, three experiments were carried out on the $Q$ strain. In Exps. 1 and 2, mice were paired (one male to one female) and the females examined daily for vaginal plugs. When a plug was found (Day 0 ) the female was transferred to a clean cage with fresh bedding. About half the females were transferred with their original male (controls); the remaining females were given a different male when transferred to the clean cage (Table 1). All females were examined daily for a second plug from Day 2 to Day 8 inclusive. In Exp. 3, the mice were mated in triads (one male to two females). One of the females, chosen at random, was removed when the plug was found and put into a cage with a different male, while the other female was left with her original male as a control. Vaginal smears were examined daily. In half the females plugs were removed by forceps as soon as they were found, to see whether this made the female more susceptible to pregnancy-block, but it had no effect.

In Cambridge, comparisons were made between the incidence of pregnancyblock in the $Q$ and $P$ strains. The tests were carried out as described by Bruce (1963). The $Q$ strain females were sent by train from Edinburgh to Cambridge and the tests were started immediately after their arrival or as indicated in the text. Observations were also made on the oestrous response of $Q$ and $P$ strain females to the presence of a male. In an attempt to simulate some of the effects of the journey to which the $Q$ strain mice had been subjected, the $\mathrm{P}$ females for this comparison were obtained from another laboratory in Cambridge. Hence all the females were subjected to a change of environment and of attendant, in addition to the specific demands of the experiment. The females of each strain were put in a single stock box on arrival. Each individual was permanently identified, and thereafter the incidence of oestrus in the two separate groups was recorded daily by means of vaginal smears. Three weeks later, two males of the $\mathrm{CBA} / \mathrm{H}$ strain were put inside each of the boxes containing the females. Each male was caged separately. Twelve days later, the cages containing the males were removed. The observations were continued for a further 12 days.

\section{RESULTS}

\section{Low response to pregnancy-block}

Table 1 gives the results of the first (Edinburgh) set of experiments. The incidence of blocked pregnancies among $Q$ females exposed to a second male was higher than among females not so exposed, but the rate of failure of pregnancy from this cause $(9.3 \%)$ was much lower than the rates of 33 to $69 \%$ reported for other strains (Bruce, 1963).

Table 2 gives the results of a direct comparison between the responses of females of the $Q$ and $P$ strains when offered the same test of olfactory discrimination. This confirmed the resistance shown by the $Q$ females, in which $20 \%$ of pregnancies were blocked as compared with $54 \%$ among $P$ strain females $(P=0.05)$. 
TABLE 1

FREQUENCY OF BLOGKED PREGNANCIES IN Q STRAIN FEMALE MICE

\begin{tabular}{|c|c|c|c|c|}
\hline \multirow{2}{*}{ Expt. No. } & \multicolumn{2}{|c|}{ Strains of males } & \multicolumn{2}{|c|}{ Females returned to oestrus } \\
\hline & Stud & Strange & Test & Control \\
\hline 1 & $Q$ & $Q$ & $3 / 34$ & $1 / 30$ \\
\hline 2 & $\begin{array}{l}\text { JU } \\
\text { CBA } \\
\text { JU } \\
\text { C57BL }\end{array}$ & $\left.\begin{array}{l}\mathrm{CBA} \\
\mathrm{JU} \\
\mathrm{C} 57 \mathrm{BL} \\
\mathrm{JU}\end{array}\right\}$ & $\left.\begin{array}{c}0 / 24 \\
3 / 18\end{array}\right\}$ & $0 / 17$ \\
\hline 3 & $\stackrel{Q}{Q}$ & $\begin{array}{l}\text { CBA } \\
\text { C57BL }\end{array}$ & $\left.\begin{array}{l}3 / 32 \\
4 / 32\end{array}\right\}$ & $1 / 64$ \\
\hline Total & & & $13 / 140$ & $2 / 111$ \\
\hline $\begin{array}{l}\text { Percentage blocked } \\
95 \% \text { confidence limits }\end{array}$ & & & $\begin{array}{c}9 \cdot 3 \\
5 \cdot 5 \text { to } 16 \cdot 1 \%\end{array}$ & 0.2 to $6.4 \%$ \\
\hline
\end{tabular}

Difference in percentage blocked, test versus control: $\chi^{2}=4 \cdot 9, P \sim 0 \cdot 05$.

\section{Oestrous response}

By contrast with their respective reactions to pregnancy-block, the oestrous response of virgin females of the two strains to the presence of males was almost identical (Table 3, Text-fig. 1). The incidence of oestrus in both groups was virtually doubled in the presence of males. Of twenty $Q$ females, seventeen came into heat within 4 days of the introduction of the males, ten of them on Day 3. Hence the failure of $Q$ females to manifest pregnancy-block cannot be attributed to an olfactory defect.

\section{Effect of handling}

By the time that the observations on the oestrous cycle had been completed and the females paired with males preparatory to a test of pregnancy-block, a striking change in sensitivity had taken place. The $Q$ strain females now resembled those of the $\mathbf{P}$ strain. The only apparent difference in treatment between this group of females, and those which had manifest a low response to pregnancy-block, lay in the handling to which the former had been subjected before the test; for in the earlier experiments, both in Edinburgh and in Cambridge, the females were not handled regularly until they were paired with males.

TABLE 2

PREGNANGY-BLOGK: GOMPARISON BETWEEN P AND Q STRAINS

\begin{tabular}{|c|c|c|c|}
\hline \multicolumn{2}{|c|}{ Strains of males } & \multicolumn{2}{|c|}{ Females returned to oestrus } \\
\hline Stud & Strange & Q strain & $P$ strain \\
\hline $\begin{array}{l}\text { TO } \\
\text { P } \\
\text { CBA } \\
\text { Total }\end{array}$ & $\left.\begin{array}{l}\mathrm{P} \\
\mathrm{CBA}\end{array}\right\}$ & $\begin{array}{l}1 / 9 \\
4 / 16 \\
5 / 25(20 \%)\end{array}$ & $\begin{array}{l}15 / 29 \\
10 / 17 \\
25 / 46(54 \%)\end{array}$ \\
\hline
\end{tabular}

Significance of difference: $P=0.05$. 
The effect of handling on the incidence of pregnancy-block was therefore examined with two groups of $Q$ females. Those of group 1 were treated as in the earlier experiments: they were paired with males (one male and two females)

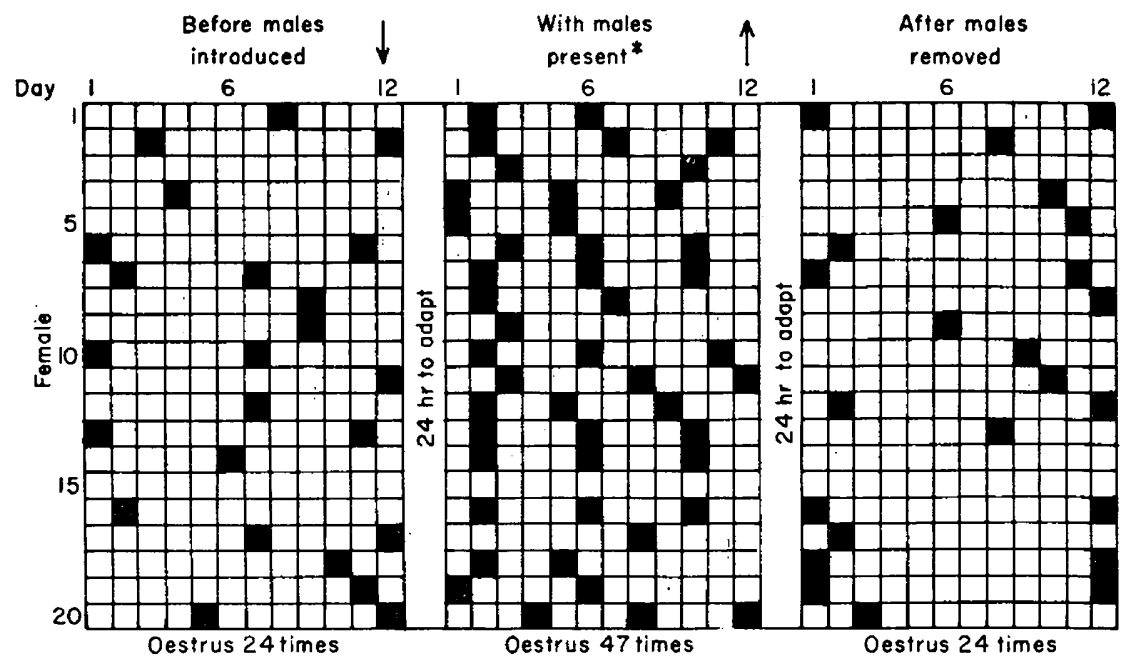

Text-Fig. 1. Social effects on oestrus in $Q$ mice. Females were housed in a stock box containing two small cages. $\downarrow$, Males introduced; $\uparrow$, males removed; * Two CBA males caged individually inside stock box with females; $\mathbf{E}$, vaginal smear cornified.

on arrival in Cambridge and vaginal smears were taken daily until the end of the test. Those of group 2 were put together in a stock box on arrival in Cambridge and vaginal smears taken daily from them for 7 to 9 weeks before they

TABLE 3

OESTROUS RESPONSE: COMPARISON BETWEEN P AND Q STRAINS

\begin{tabular}{c|c|c|cccc}
\hline & & \multicolumn{5}{|c}{ Incidence of oestrus in 12 days } \\
\cline { 2 - 7 } $\begin{array}{c}\text { Grouped in stock } \\
\text { box containing } \\
\text { two small cages }\end{array}$ & $\begin{array}{c}\text { Social } \\
\text { condition* }\end{array}$ & $\begin{array}{c}\text { Total } \\
\text { per } \\
\text { group }\end{array}$ & \multicolumn{5}{|c}{ Oestrus/female } \\
\hline 18 P females & A & 19 & 2 & 13 & 2 & 3 \\
& B & 40 & 3 & 14 & 12 & 5 \\
& C & 16 & & 1 & \\
\hline 20 Q females & A & 24 & 3 & 10 & 7 & \\
& B & 47 & 1 & 2 & 6 & 11 \\
& C & 24 & 3 & 10 & 7 & \\
\hline
\end{tabular}

* A, Before introduction of males; $\mathrm{B}, \mathrm{CBA} / \mathrm{H}$ males present in each cage; $\mathrm{C}$, after removal of males. The females were allowed 3 weeks for adaptation before the introduction of the males, and $24 \mathrm{hr}$ between conditions $\mathrm{A}$ and $\mathrm{B}$ and between $\mathrm{B}$ and $\mathrm{C}$.

were paired with stud males. Hence, when tested for pregnancy-block, they had had the opportunity to become adapted to this daily routine. $\mathrm{P}$ females (group 3), not previously handled, were tested concurrently with each group of $Q$ females. The results are summarized in Table 4.

The comparison of the $Q$ and $P$ females, when both were tested without 
prior handling, confirmed the difference in the frequency of blocked pregnancies; but preliminary handling of the $Q$ females increased the incidence, almost to that of the $\mathrm{P}$ females.

TABLE 4

EFFEGT OF PREVIOUS HANDLING ON PREGNANGY-BLOGK RESPONSE IN Q FEMALES

\begin{tabular}{c|c|c|rr}
\hline Group & $\begin{array}{c}\text { Strain of } \\
\text { female }\end{array}$ & $\begin{array}{c}\text { Previous } \\
\text { handling }\end{array}$ & \multicolumn{2}{|c}{$\begin{array}{c}\text { Females returned } \\
\text { to oestrus }\end{array}$} \\
\hline 1 & $\mathrm{Q}$ & Without & $9 / 43$ & $21 \%$ \\
2 & $\mathrm{Q}$ & With* & $17 / 35$ & $49 \%$ \\
3 & $\mathrm{P}$ & Without & $48 / 82$ & $55 \%$ \\
\hline
\end{tabular}

Significance of differences: 1 versus $2, P=0.05$; 1 versus $3, P=0.01 ; 2$ versus 3 , N.S.

* Vaginal smears taken daily for 7 to 9 weeks before the females were paired with males.

\section{DISGUSSION}

When first handled, $Q$ strain females are nervous and, in the experience of one of us (H.M.B.), require at least 10 to 14 days of daily examination before they settle down. P females, by contrast, are docile from the start. Resistance to pregnancy-block apparently develops when a recently mated $Q$ female is subjected to the mild stimulus of daily handling. Since resistance was found among mice tested in Edinburgh, in the laboratory in which they had been bred, as well as after the journey to Cambridge, the disturbance induced by travel is probably not implicated. The behaviour manifest by $Q$ females when first handled resembles rather similar behaviour in rats. Vogt (1951) states that "rats submitted for the first time to measurements of rectal temperature respond to this unaccustomed procedure by a fall of adrenal ascorbic acid . . the ascorbic acid remained unaffected in 'trained' rats'. D'Arcy (1962) has emphasized the importance of allowing animals to become familiar with the precise conditions and procedures of experiment before undertaking bio-assay; he gives examples relating to rabbits, rats and mice.

Implantation is influenced by a variety of environmental stimuli. Changes in housing conditions alone interfere with pregnancy in Peromyscus (Eleftheriou et al., 1962), in wild house mice (Chipman \& Fox, 1966) and even in the domesticated laboratory mouse (Bruce, 1963). The presence of other females possibly helps to stabilize pregnancy (Bruce, 1959) as well as to confer some degree of resistance to pregnancy-block (Bruce, 1963). These are subtle effects and little is known at present of the interplay between the factors which bring them about. Our observations make it inappropriate to refer to $Q$ strain females as 'resistant' to the blocking of pregnancy; rather they are so sensitive to unaccustomed handling that the olfactory block to implantation is itself inhibited unless the females are already habituated to handling.

\section{AGKNOWLEDGMENTS}

The work in Cambridge was supported by the Medical Research Council from whom one of us (H.M.B.) gratefully acknowledges the receipt of a personal 
grant. R. B. Land is indebted to the Agricultural Research Council for a postgraduate studentship and to the Ford Foundation for further financial support during this work. We also thank Miss C. Fullerton of the Department of Psychology, University of Aberdeen for assistance with some of the Cambridge tests.

\section{REFERENCES}

BRUGe, H. M. (1959) An exteroceptive block to pregnancy in the mouse. Nature, Lond. 184, 105.

BRUCE, H. M. (1963) Olfactory block to pregnancy among grouped mice. F. Reprod. Fert. 6, 451.

BRUCE, H. M. (1966) Smell as an exteroceptive factor. F. Anim. Sci. 25, Supplement, p. 83.

Bruce, H. M. \& ParrotT, D. M. V. (1960) Role of olfactory sense in pregnancy block by strange males. Science, N.Y. 131, 1526.

Chipman, R. K. \& Fox, K. A. (1966) Oestrous synchronization and pregnancy blocking in wild house mice (Mus musculus). J. Reprod. Fert. 12, 233.

D'Arcy, P. F. (1962) The conditioning of experimental animals. 7. Pharm. Pharmac. 14, 411.

Eleptheriou, B. E., Bronson, F. H. \& ZarRow, M. X. (1962) Interaction of olfactory and other environmental stimuli on implantation in the deer mouse. Science, $\mathcal{N} . Y .137,764$.

Marsden, H. M. \& Bronson, F. H. (1965) Strange male block to pregnancy: its absence in inbred mouse strains. Nature, Lond. 184, 105.

Vogr, M. (1951) The effect of emotion and of $\beta$-tetrahydronaphthylamine on the adrenal cortex of the rat. F. Physiol., Lond. 114, 465.

Whitten, W. K. (1956) Modification of the oestrous cycle of the mouse by external stimuli associated with the male. F. Endocr. 13, 399.

WhItTEN, W. K. (1958) Modification of the oestrous cycle of the mouse by external stimuli associated with the male. Changes in the oestrous cycle determined by vaginal smears. J. Endocr. 17, 307. 